\title{
USING DEWATERED SLUDGE FROM A DRINKING WATER TREATMENT PLANT FOR PHOSPHORUS REMOVAL IN CONSTRUCTED WETLANDS
}

\author{
NURIA OLIVER ${ }^{1}$, CARMEN HERNÁNDEZ-CRESPO $^{2}$, MARIA PEÑA $^{1}$, MIGUEL AÑÓ$^{1}$, \\ ADRÍAN MARTÍNEZ ${ }^{3} \&$ MIGUEL MARTIIN ${ }^{2}$ \\ ${ }^{1}$ Global Omnium, Spain \\ ${ }^{2}$ Instituto De Ingeniería Del Agua Y Medio Ambiente, Universitat Politècnica De València, Spain \\ ${ }^{3}$ Departamento Ingeniería Hidráulica Y Medio Ambiente, Universitat Politècnica De València, Spain
}

\begin{abstract}
This study evaluates the applicability of drinking water sludge as an active substrate in vertical subsurface flow constructed wetlands (VFCW) for advanced wastewater treatment. This treatment enables the achievement of greater phosphorus removals, as well as other pollutants, reaching concentrations below the required limits and obtaining suitable water for different uses, particularly environmental ones. To this end, two prototypes, one of them operating intermittently and another one with continuous flow, have been installed at Quart-Benàger urban wastewater treatment plant (WWTP), facility property of Entidad Pública de Saneamiento de Aguas Residuales (EPSAR) of the Valencian region. Preliminary results indicate that the reuse of the drinking water sludge as an active substrate in VFCW improves the quality of WWTP effluents, minimizing their impact on the receiving aquatic environments.
\end{abstract}

Keywords: pilot scale, phosphorus removal, reuse, drinking water sludge, subsurface flow constructed wetlands.

\section{INTRODUCTION}

Despite the fact that in recent decades a great effort has been made to improve the environmental quality of European water bodies, only $40 \%$ of the surface waters reached the ecological status "good" or "very good" stipulated by the Water Framework Directive (WFD, Directive 2000/60/EC) during the surveillance monitoring period 2010-2015 [1]. These data show the need to look for sustainable and economically viable solutions that guarantee the supply of good quality water to these ecosystems, allowing them to improve their ecological and chemical status, as well as maintaining the multiple services that they provide us.

In addition, the UN [2] warns that the world population is expected to increase by more than 1 billion inhabitants in the next 10 years, so that by 2030 there will be 8.6 billion inhabitants. This fact is going to lead to an important increase both in the impacts and in the demands of natural resources, and more specifically on water. This problem is aggravated in arid or semi-arid regions where water scarcity is a chronic problem, and it is essential to carry out adequate comprehensive water management so that it is returned to the receiving environment with adequate quality. In this sense, a higher purification level guarantees a better quality of the water in the receiving environment, with better oxygenation levels, thus mitigating the effects of the increase in temperature associated with climate change [3].

In Spain, $72 \%$ of the municipalities have a population of less than 2,000 inhabitants, according to the National Statistics Institute, some of which do not have a wastewater treatment plant (WWTP) or it does not work properly. Together, these municipalities house a total population of two million seven hundred thousand inhabitants, which supposes a polluting load of approximately 162 tons of organic matter per day. Although the pollutant load of each of these municipalities may seem small, the problem lies in the fact that their 
discharges are normally located in headwaters of rivers or in small streams, with limited dilution capacity and in many cases of high ecological value. Therefore, in small towns, the water sector must adapt to the new regulatory requirements regarding water, applying technologies adapted to the rural environment, such as constructed wetlands (CW). In this sense, the WFD involved a paradigm shift in the control of discharges into the aquatic environment, going from having to meet discharge limits to meeting quality objectives in the water bodies, which implied that the discharge authorizations should contemplate these environmental objectives when setting the discharge requirements in each case.

$\mathrm{CW}$ are water treatment infrastructures where physical, chemical and biological processes normally occurring in natural wetlands are reproduced in a controlled way, giving a treated effluent. In recent decades, numerous case studies have shown that these systems are a real alternative to conventional wastewater treatment technologies in small populations $(<2000$ h.e.). Among its advantages, we can highlight: high efficiency in the removal of organic matter and suspended solids, very simple maintenance, no or little energy consumption, little generation of sludge and no use of chemical products. However, it is difficult to achieve a high elimination of inorganic nutrients (orthophosphates and ammonium) [4]. The most widely used technology for the removal of phosphorus in CW is based on the use of active substrates as filling material [5], [6].

Another environmental problem that humanity faces is the large amount of solid waste generated from productive activities and whose management is inefficient. In the field of the Integral Water Cycle, and specifically in the water purification process, large amounts of sludge are produced, as a result of the applied physical-chemical treatments. Currently, it is estimated that each year around $3.8 \mathrm{~kg} \cdot$ person $^{-1}$ of this "waste" is generated worldwide [7], and its global production probably exceeds $10,000 \mathrm{tn} \cdot \mathrm{day}^{-1}[8]$, with expectations that it will increase in the future.

In Europe, this waste is considered non-hazardous waste on the European waste list (LER 190902) and therefore it is usually disposed in landfills, thereby increasing the overall costs, both economic and environmental, of water treatment [9]. This fact highlights the need to find efficient and sustainable alternatives for its management.

One of the properties that characterizes this sludge, when aluminium salts are used as a chemical coagulant during the water purification process, is that it has a high chemical affinity for phosphorus (P). Previous investigations have verified that its use in wastewater treatment improves the processes of adsorption and chemical precipitation of phosphorus [10]-[13] in addition to other contaminants.

In this work, the applicability of the sludge produced in one Drinking Water Treatment Plant (DWTP) as an active substrate in CW with vertical subsurface flow (VFCW) is evaluated. These wetlands would be destined for an advanced urban wastewater treatment, after a secondary treatment, with the aim of obtaining an enhanced effluent suitable for different uses, especially environmental (wetland maintenance, ecological flows, etc.). The initial hypothesis is that the sludge still maintains a certain capacity for the elimination of substances through sorption or chemical precipitation processes and that plants and biofilm can complement the treatment with other biochemical processes.

Underlying the spirit of the project is the objective of moving towards a sustainable development, applying the principles of circular economy in the Integral Water Cycle (Fig. 1). To evaluate the efficiency of this treatment, two VFCW prototypes have been installed in the Quart-Benàger WWTP (Valencia) for treating a part of the effluent from the secondary treatment (prior to disinfection). 


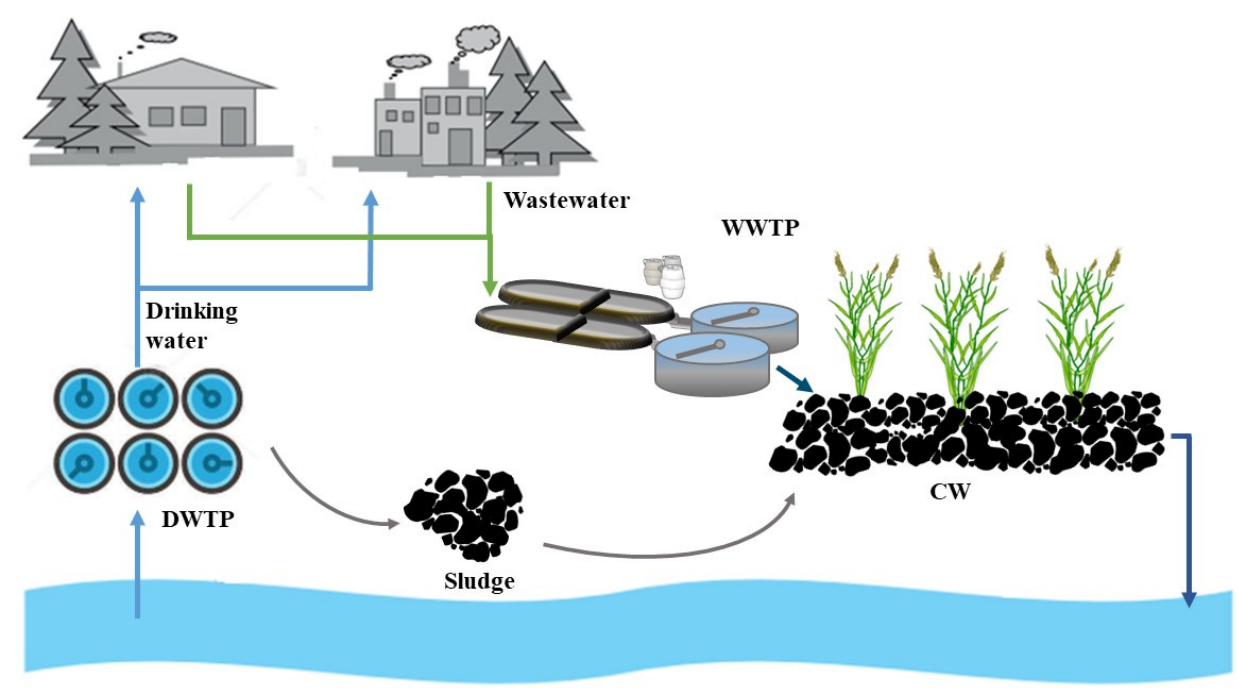

Figure 1: Use of the sludge produced in the DWTP as an active substrate for CW in the final phase of the Integral Water Cycle [14].

\section{MATERIALS AND METHODS}

Two prototypes with a surface of $1 \mathrm{~m}^{2}$ were installed in the Quart-Benàger WWTP, facility property of EPSAR, attached to Conselleria de Agricultura, Desarrollo Rural, Emergencia Climatic y Transición Ecológica, QB-WWTP hereafter (Valencia, Spain). They were filled with two layers of gravels (size: $10-11 \mathrm{~mm}$ ) at bottom and surface, and three intermediate layers of sludge from the DWTP La Presa (Manises, Valencia, Spain), with the granulometry and thickness indicated in Fig. 2. The planted vegetation was Phragmites australis (common reed), one of the typical species of the humid zones and commonly used in CW [15], with an initial density of $10 \mathrm{plants} \cdot \mathrm{m}^{-2}$.

The La Presa DWTP produces approximately $12 \mathrm{~m}^{3} \cdot \mathrm{day}^{-1}$ of sludge with a humidity of around $75 \%$, which contains the particles present in raw water before treatment: suspended solids, flocculated mineral and organic materials, metallic hydroxides (iron and manganese), and the residues of the coagulants added for treatment, i.e. aluminium polychloride $\left(\mathrm{Al}_{2}(\mathrm{OH})_{3} \mathrm{Cl}\right)$ aided by a flocculant (PoliDADMAC), and powdered activated carbon. After several dehydration processes, centrifuges, and drying beds, the sludge cake reaches a dry matter content of $33 \%$. Once dried, the cakes were grinded, obtaining the grain sizes indicated in Fig. 2. The aluminium content was $709 \mathrm{mg} \cdot \mathrm{g}^{-1}$ (dry weight).

One of the prototypes worked intermittently (VFCW-1), through several equal cycles throughout the day (filling, contact time and draining), while the other prototype operated at continuous flow (VFCW-2), the substrate remaining always flooded (Fig. 2).

The study has been divided into two periods, attending to the different contact times tested in the HAFV-1 and covering the entire start-up of the prototypes. In HAFV-1 wetland, the contact time is defined as the time that elapses between the end of filling and the beginning of emptying. In HAFV-2, the contact time is the theoretical hydraulic retention time (porous volume/flow rate). The hydraulic load applied in each case, as well as the contact times maintained, are presented in Table 1. 
The performance of both pilot VFCV was monitored as follows. Samples of the influent (secondary treatment effluent of QB-WWTP) and the effluent from each prototype were collected for subsequent physical-chemical analysis. The variables analysed were: electrical conductivity, $\mathrm{pH}$ and dissolved oxygen (DO), measured in situ, turbidity, total suspended solids (TSS) and volatile (VSS), COD (total), $\mathrm{BOD}_{5}$ (total), total nitrogen (TN), ammonium $\left(\mathrm{N}-\mathrm{NH}_{4}{ }^{+}\right)$, nitrites $\left(\mathrm{N}-\mathrm{NO}_{2}{ }^{-}\right)$, nitrates $\left(\mathrm{N}-\mathrm{NO}_{3}{ }^{-}\right)$, total phosphorus $(\mathrm{PT})$, phosphates $\left(\mathrm{P}-\mathrm{PO}_{4}{ }^{3-}\right)$, aluminium (Al) and Escherichia coli (E. Coli). The latter was chosen as indicator of faecal pollution considered in water reuse regulation [16], [17]. For the physical parameters and soluble compounds, the frequency of the determinations has been 3 times per week $(n=45)$, while for the total compounds and the pathogens it has been 1 time per week $(n=16)$. All the chemical analyses have been carried out following standardized methods [18].

Finally, a statistical analysis was carried out to compare the existence of significant differences between the concentrations measured in the influent and in the effluent of each prototype, as well as between both effluents. If the samples presented normal distribution, the Student's t-test was applied for related samples, otherwise, the Friedman test was applied to analyse the relationship of different variables simultaneously and the Wilcoxon test to compare between pairs. All statistical analyses were carried out with a confidence level of $95 \%$, assuming an error of 5\%, using SPSS 15.0 software for Windows (SPSS Inc. Chicago, USA).

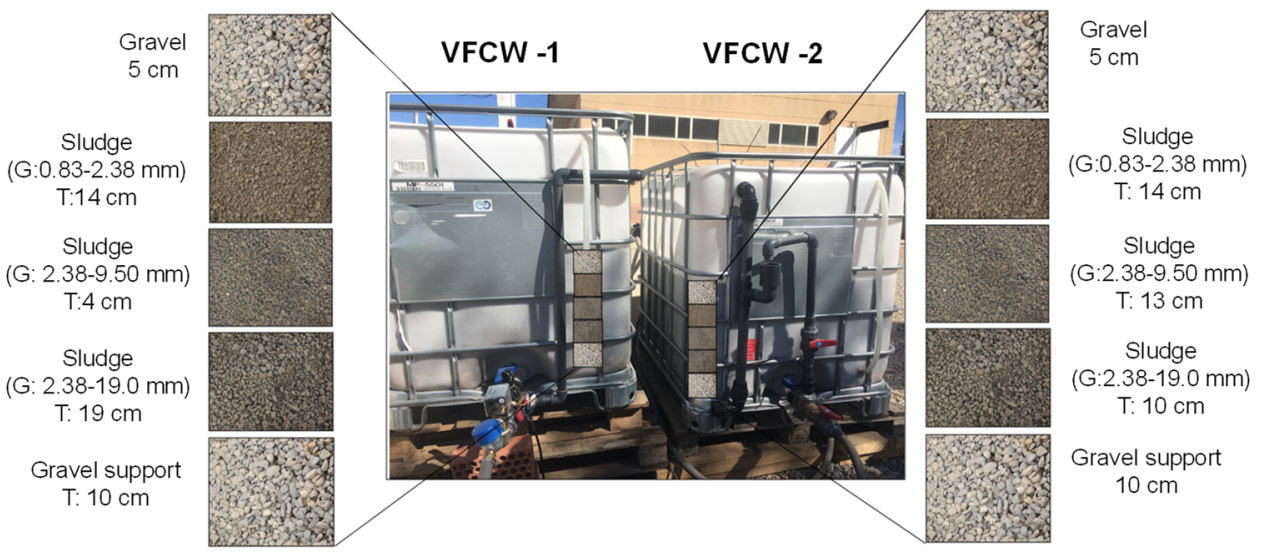

Figure 2: Prototypes image and grain size distribution (G: grain size; T: thickness).

Table 1: Hydraulic loading rates, cycles per day and contact times.

\begin{tabular}{|c|c|c|c|c|}
\cline { 2 - 5 } \multicolumn{1}{c|}{} & \multicolumn{2}{c|}{ Hydraulic loading rate $\left(\mathbf{m}^{3} \mathbf{~ m}^{-2}\right.$ day } & & \multicolumn{2}{c|}{$\begin{array}{c}\text { Contact time } \\
\text { (minutes) }\end{array}$} \\
\cline { 2 - 5 } & Period I & Period II & Period I & $\begin{array}{c}\text { Period } \\
\text { II }\end{array}$ \\
\hline VFCW-1 & $\begin{array}{c}3.75 \pm 0.60(22 \\
\text { cycles })\end{array}$ & $\begin{array}{c}3.02 \pm 0.39(18 \\
\text { cycles })\end{array}$ & 30 & 45 \\
\hline VFCW-2 & $3.09 \pm 0.48$ & $3.00 \pm 0.54$ & 120 & 120 \\
\hline
\end{tabular}


Table 2: Influent concentration to the VFCW prototypes (average \pm standard deviation for each period). The discharge limits by European and local authorities are: TSS (35 $\left.\mathrm{mg} \cdot \mathrm{L}^{-1}\right) \operatorname{COD}\left(125 \mathrm{mg} \cdot \mathrm{L}^{-1}\right)$, BOD5 $\left(25 \mathrm{mg} \cdot \mathrm{L}^{-1}\right), \mathrm{TN}\left(10 \mathrm{mg} \cdot \mathrm{L}^{-1}\right), \mathrm{TP}\left(0.6 \mathrm{mg} \cdot \mathrm{L}^{-1}\right)$.

\begin{tabular}{|c|c|c|c|}
\hline Variable & Units & Period I & Period II \\
\hline TSS & $\mathrm{mg} \mathrm{TSS} \mathrm{L}^{-1}$ & $6.9 \pm 7.5$ & $6.7 \pm 1.4$ \\
\hline COD & $\mathrm{mg} \mathrm{O}_{2} \mathrm{~L}^{-1}$ & $30 \pm 5$ & $34 \pm 4$ \\
\hline BOD5 & $\mathrm{mg} \mathrm{O}_{2} \mathrm{~L}^{-1}$ & $10 \pm 3$ & $10 \pm 2$ \\
\hline TP & $\mathrm{mg} \mathrm{P} \mathrm{L}^{-1}$ & $0.31 \pm 0.13$ & $0.59 \pm 0.16$ \\
\hline $\mathrm{PO}_{4}^{3-}$ & $\mathrm{mg} \mathrm{P}-\mathrm{PO}_{4}{ }^{3-} \mathrm{L}^{-1}$ & $0.18 \pm 0.26$ & $0.32 \pm 0.38$ \\
\hline $\mathbf{T N}$ & $\mathrm{mg} \mathrm{N} \mathrm{L}^{-1}$ & $7.69 \pm 1.71$ & $9.51 \pm 0.94$ \\
\hline $\mathbf{N H}_{4}^{+}$ & $\mathrm{mg} \mathrm{N}^{-\mathrm{NH}_{4}}{ }^{+} \mathrm{L}^{-1}$ & $2.23 \pm 1.53$ & $4.49 \pm 2.17$ \\
\hline $\mathrm{NO}_{2}^{-}$ & $\mathrm{mg} \mathrm{N}-\mathrm{NO}_{2}^{-} \mathrm{L}^{-1} 1$ & $0.68 \pm 0.44$ & $0.90 \pm 0.28$ \\
\hline $\mathrm{NO}_{3}^{-}$ & $\mathrm{mg} \mathrm{N}-\mathrm{NO}_{3}-\mathrm{L}^{-1}$ & $4.02 \pm 1.46$ & $4.12 \pm 0.72$ \\
\hline E. Coli & $\log _{10} \mathrm{CFU} 100 \mathrm{~mL}^{-1}$ & $4.9 \pm 0.3$ & $5.1 \pm 0.4$ \\
\hline
\end{tabular}

\section{RESULTS AND DISCUSSION}

\subsection{Influent characteristics}

The results of physic-chemical characteristics of the influent to the VFCW prototypes during the study period are shown in Table 2 . It should be highlighted that the results indicate very low concentrations, due to the fact that this is the effluent from the secondary treatment of the WWTP, as previously mentioned, which must meet not only the discharge requirements to a sensitive area (91/271/EEC Directive) but those established for the TP by the water authority (Jucar Hydrographic Confederation). Thus, the average value of TP was less than $0.6 \mathrm{mg} \mathrm{P} \mathrm{L}^{-1}$ and average TN was $10 \mathrm{mg} \mathrm{N} \mathrm{L}^{-1}$, with nitrates being the major component.

\subsection{Removal efficiencies}

The average concentrations of effluent and removal efficiencies for each variable, period and prototype are indicated in Table 3 and Fig. 3 respectively. The mean effluent concentration of TP was significantly lower than that measured in the influent $(p<0.05)$ for both prototypes and well below the limit required for this WWTP. It is in the order of $0.1 \mathrm{mg} \mathrm{P} \mathrm{L}{ }^{-1}$, a value recommended for the Albufera Lake restoration [19]. Regarding phosphates, the concentrations measured in the effluents were also significantly lower than those of the influent $(p<0.05)$, this reduction being mainly related to the adsorption and precipitation processes in the active substrate. Proof of this is the high efficiency achieved since the beginning of the prototypes' start-up, with vegetation and a biofilm not yet developed. The VFCW-2 prototype presented a significantly lower concentration, thus a higher efficiency, probably because it has a higher proportion of sludge with a smaller grain size (Fig. 2). In this sense, it is well known that the higher the specific surface area of the substrate, the greater its adsorption capacity [20]. Nevertheless, despite the differences found, the removal efficiencies achieved in both prototypes can be considered high (Fig. 3), exceeding $80 \%$ with the continuous operation mode (VFCW-2). In the case of VFCW-1, the TP removal efficiency improved with increasing the contact time (period II) and could also be related to a greater development of biofilm and vegetation. 
Table 3: Effluent concentration from the VFCW prototypes (average \pm standard deviation for each period).

\begin{tabular}{|c|c|c|c|c|c|}
\hline \multirow{2}{*}{ Variable } & \multirow{2}{*}{ Units } & \multicolumn{2}{|c|}{ Period I } & \multicolumn{2}{|c|}{ Period II } \\
\hline & & VFCW-1 & VFCW-2 & VFCW-1 & VFCW-2 \\
\hline SST & mg TSS L ${ }^{-1}$ & $2.5 \pm 1.6$ & $1.9 \pm 1.2$ & $2.5 \pm 0.5$ & $2.3 \pm 0.5$ \\
\hline COD & $\mathrm{mg} \mathrm{O}_{2} \mathrm{~L}^{-1}$ & $21 \pm 1$ & $19 \pm 2$ & $19 \pm 2$ & $21 \pm 2$ \\
\hline BOD5 & $\mathrm{mg} \mathrm{O}_{2} \mathrm{~L}^{-1}$ & $4 \pm 2$ & $4 \pm 1$ & $5 \pm 2$ & $5 \pm 1$ \\
\hline $\mathbf{T P}$ & $\mathrm{mg} \mathrm{P} \mathrm{L}^{-1}$ & $0.12 \pm 0.02$ & $0.05 \pm 0.01$ & $0.18 \pm 0.03$ & $0.07 \pm 0.02$ \\
\hline $\mathrm{PO}_{4}{ }^{3-}$ & $\mathrm{mg} \mathrm{P}_{-} \mathrm{PO}_{4}{ }^{3-} \mathrm{L}^{-1}$ & $0.06 \pm 0.04$ & $0.01 \pm 0.02$ & $0.08 \pm 0.03$ & $0.03 \pm 0.03$ \\
\hline $\mathbf{T N}$ & $\operatorname{mg~N~L} ~^{-1}$ & $7.92 \pm 0.99$ & $6.05 \pm 1.26$ & $9.19 \pm 0.59$ & $4.90 \pm 0.78$ \\
\hline $\mathrm{NH}_{4}^{+}$ & $\operatorname{mg~N}-\mathrm{NH}_{4}{ }^{+} \mathrm{L}^{-1}$ & $0.11 \pm 0.13$ & $1.89 \pm 1.06$ & $0.14 \pm 0.15$ & $2.63 \pm 1.56$ \\
\hline $\mathrm{NO}_{2}^{-}$ & $m g ~ N-N_{2}{ }^{-} \mathrm{L}^{-1}$ & $0.09 \pm 0.10$ & $0.36 \pm 0.24$ & $0.09 \pm 0.08$ & $0.00 \pm 0.01$ \\
\hline $\mathrm{NO}_{3}^{-}$ & $\mathrm{mg} \mathrm{N}-\mathrm{NO}_{3}^{-} \mathrm{L}^{-1}$ & $6.89 \pm 1.47$ & $3.28 \pm 1.13$ & $8.37 \pm 0.87$ & $1.58 \pm 0.66$ \\
\hline E. Coli & $\log _{10}$ CFU $100 \mathrm{~m} \mathrm{~L}^{-1}$ & $4.2 \pm 0.6$ & $3.4 \pm 0.4$ & $3.8 \pm 0.7$ & $3.7 \pm 0.5$ \\
\hline
\end{tabular}

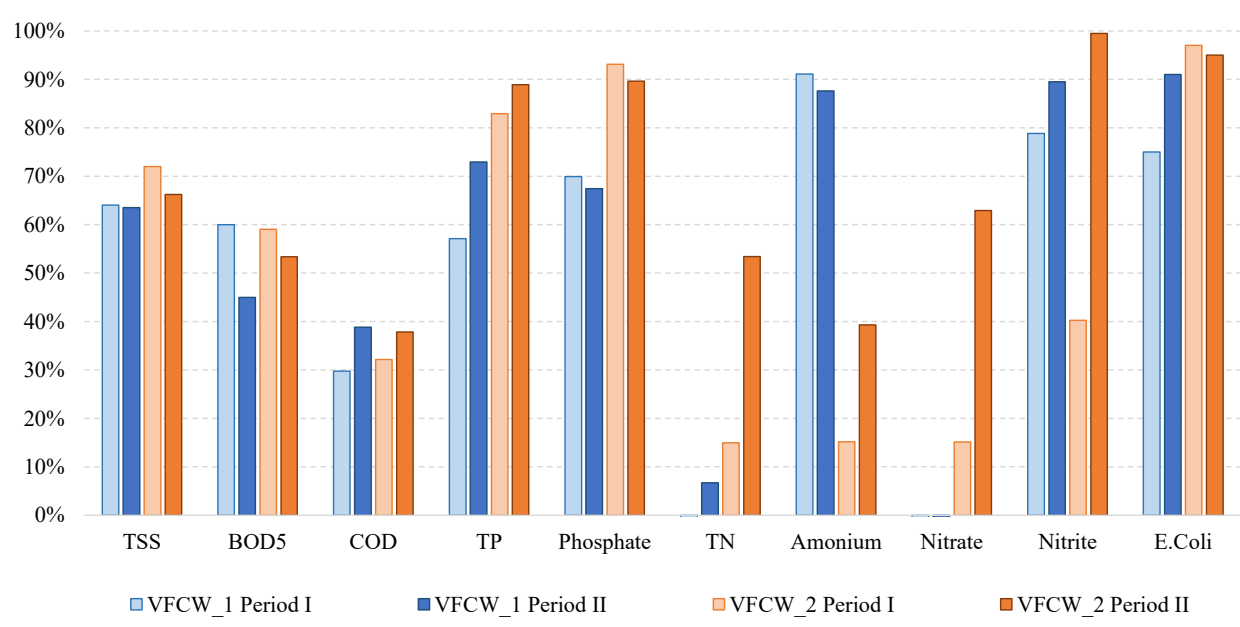

Figure 3: Mean removal efficiencies in each prototype and period.

Regarding TSS, both prototypes significantly reduced its concentration $(\mathrm{p}<0.05)$. In fact, the average value obtained, around $2 \mathrm{mg} \mathrm{L}^{-1}$, is even lower than the average values measured in river water bodies protected by Red Natura 2000 [21]. Similarly to TP, the TSS retention efficiency was high from the beginning, greater than $60 \%$. This TSS reduction is associated with the combination of sedimentation processes (as they slowly pass through the porous bed) and filtration.

The organic matter present in the influent to the prototypes, measured as COD and $\mathrm{BOD}_{5}$, was low because it is the effluent from the secondary treatment of the QB-WWTP, thus can be characterized as slowly biodegradable. However, despite this, its concentration was further reduced as it passed through the VFCW, reaching mean concentrations of biodegradable organic matter below $5 \mathrm{mg} \mathrm{O}_{2} \cdot \mathrm{L}^{-1}$. This value is below the limit established in 
the Spanish Hydrological Planning Instruction to define the good status of rivers $\left(6 \mathrm{mg} \cdot \mathrm{L}^{-1}\right)$ [22], therefore the effluent has a very good water quality. The average removal efficiencies achieved for COD were above $30 \%$ and up to $60 \%$ for $\mathrm{BOD}_{5}$.

With regard to TN, the behaviour of both VFCW prototypes was different. VFCW-1 significantly reduced the ammonium concentration $(p<0.05)$ because it has aerobic conditions thanks to the intermittent regime, which enables the oxygenation of the substrate during the draining stage, thus favouring the nitrification process. In line with this, TN did not decrease because ammonium was transformed into nitrates. Conversely, VFCW-2 has more anoxic conditions due to its continuous feeding, which promotes the denitrification process. Indeed, nitrates decreased significantly $(p<0.05)$, thus reducing TN as well, whereas ammonium removal efficiency was low $(15 \%)$ because of the anoxic conditions. Interestingly, this removal efficiency was significantly improved in the second period of the study (Fig. 3), coinciding with better environmental conditions for the nitrification-denitrification process (more developed root system and biofilm and higher temperatures), as well as a consumption of soluble inorganic nitrogen (preferably ammoniacal nitrogen) by vegetation. The latter, together with the increase of the contact time in HAFV-1, could have led to the net removal achieved in this prototype during the second period.

In addition to the parameters discussed so far, since it is intended to reuse the reclaimed water, it is crucial to guarantee very good quality conditions regarding the content of pathogenic microorganisms. Thus, the measured concentrations of E. Coli in the effluents of both prototypes (Table 2) were significantly lower than those measured in the influent $(p<0.05)$, reaching average removal yields of up to $91 \%$ in HAFV-1 and up to $97 \%$ in HAFV-2. Moreover, in the case of HAFV-1, the removal efficiency improved significantly by increasing the contact time. Keeping in mind that one of the objectives is to meet the quality requirements for reusing the reclaimed water, this is an important finding in order to define the best operation conditions. It should be noted that during the second study period, both prototypes obtained a concentration of E. Coli in the effluent below 4.00 logarithmic units of CFU $100 \mathrm{~mL}^{-1}$, thus accomplishing the limit value for the irrigation of woody crops, tree nurseries or industrial crops [16].

The removal of microorganisms is a highly complex process. Processes such as filtration, adsorption, and predation play a fundamental role in this type of wetland systems. In addition, the removal is dependent on the residence time and the granular medium, so that the smaller its diameter, the greater efficiency obtained.

Finally, given the presence of aluminium in the sludge, one might wonder if there is a risk of releasing this metal into the water flowing through the material. The results indicate that, concentrations never reached values higher than $0.2 \mathrm{mg} \cdot \mathrm{L}^{-1}$, which is the value stipulated by European Directive dealing with the sanitary criteria for the quality of water for human consumption [23].

\section{CONCLUSIONS}

The results of this study have shown that the sludge produced in "La Presa" DWTP can be used as main substrate of $\mathrm{CW}$ for improving the water quality of secondary effluents in WWTPs. It is a good adsorbent of phosphorus, as well as an appropriate media for the development of biofilm and typical vegetation of $\mathrm{CW}$. Therefore, this technology has proven to be efficient for the advanced treatment of urban wastewater, significantly improving the quality of the effluents of WWTPs. More interestingly, the reclaimed water could be directly reused for some uses, without needing an additional disinfection treatment. 
Thanks to the use of this kind of system, it is possible to achieve a phosphorus concentration in the effluent lower than $0.1 \mathrm{mg} \mathrm{P} \cdot \mathrm{L}^{-1}$, a value considerably lower than the limit established by the Jucar Basin Hydrological Plan $\left(0.6 \mathrm{mg} \mathrm{P} \cdot \mathrm{L}^{-1}\right)$, with HLR between $2.72-2.81 \mathrm{~m}^{3} \mathrm{~m}^{-2} \mathrm{~d}^{1}$. In addition, it contributes to reducing other pollutants such as total nitrogen, ammonium, $\mathrm{BOD}_{5}$ and $\mathrm{COD}$, still present, although in very low concentrations, in the secondary effluent of an activated sludge treatment.

The choice of one or the other type of mode of operation (HAFV-1 or HAFV-2) will depend on the quality objectives pursued for the effluent of the WWTP.

\section{ACKNOWLEDGEMENTS}

Research partially funded by the Generalitat Valenciana-IVACE (Valencian Institute of Business Competitiveness) and by the European Regional Development Fund (through the ERDF Operational Program for the Valencian Community 2014-2020).

The authors want to express their gratitude to the Public Entity for Wastewater Sanitation of the Valencian Community (EPSAR), as well as to the Cathedra "Aguas de Valencia-Universitat Politècnica de València," Department of Hydraulic Engineering and the Environment.

\section{REFERENCES}

[1] European Environment Agency (EEA). European waters-assessment of status and pressures. EEA Report No 7/2018. EEA, Copenhagen, 2018.

[2] UN. Department of Economic and Social Affairs, 2017. www.un.org/development/ desa/es/news/population/world-population-prospects-2017.html.

[3] Vaughan, I.P. \& Gotelli, N.J., Water quality improvements offset the climatic debt for stream macroinvertebrates over twenty years. Nature Communications, 10, 2019. DOI: $10.1038 / \mathrm{s} 41467-019-09736-3$.

[4] Vymazal, J., Removal of nutrients in various types of constructed wetlands. Science of the Total Environment, 380(1-3), pp. 48-65, 2007.

[5] Martín, M., Gargallo, S., Hernández-Crespo, C. \& Oliver, N., Phosphorus and nitrogen removal from tertiary treated urban wastewaters by a vertical flow constructed wetland. Ecological Engineering, 61, pp. 34-42, 2013.

[6] Vohla, C., Kõiv, M., Bavor, H.J., Chazarenc, F. \& Mander, Ü., Filter materials for phosphorus removal from wastewater in treatment wetlands: A review. Ecological Engineering, 37(1), 70-89, 2011.

[7] Zhao, Y., Liu, R., Awe, O.W., Yang, Y. \& Shen, C., Acceptability of land application of alum-based water treatment residuals-an explicit and comprehensive review. Chemical Engineering Journal, 353, pp. 717-726, 2018.

[8] Turner, T., Wheele, R., Stone, A. \& Oliver, I., Potential alternative reuse pathways for water treatment residuals: Remaining barriers and questions: A review. Water Air \& Soil Pollution, 230, 2019.

[9] Hidalgo, A.M., Murcia, M.D., Gómez, M., Gómez, E., García-Izquierdo, C. \& Solano, C., Possible uses for sludge from drinking water treatment plants. Journal of Environmental Engineering, 143(3), pp. 04016088, 2017.

[10] Babatunde, A.O. \& Zhao, Y.Q., Constructive approaches toward water treatment works sludge management: An international review of beneficial reuses. Critical Reviews in Environmental Science and Technology, 37(2), pp. 129-64, 2007.

[11] Babatunde, A.O. \& Zhao, Y.Q., Forms, patterns and extractability of phosphorus retained in alum sludge used as substrate in laboratory-scale constructed wetland systems. Chemical Engineering Journal, 152(1), pp. 8-13, 2009. 
[12] Babatunde, A. O., Zhao, Y.Q. \& Zhao, X.H., Alum sludge-based constructed wetland system for enhanced removal of $\mathrm{P}$ and $\mathrm{OM}$ from wastewater: Concept, design and performance analysis. Bioresource Technology, 101(16), pp. 6576-79, 2010.

[13] Zhao, Y.Q., Babatunde, A.O., Razali, M. \& Harty, F., Use of dewatered alum sludge as a substrate in reed bed treatment systems for wastewater treatment. Journal of Environmental Science and Health - Part A Toxic/Hazardous Substances and Environmental Engineering, 43(1), pp. 105-10, 2008.

[14] Zhao, Y.Q., Babatunde, A.O., Hu, Y.S., Kumar, J.L.G. \& Zhao, X.H., Pilot field-scale demonstration of a novel alum sludge-based constructed wetland system for enhanced wastewater treatment. Process Biochemistry, 46(1), pp. 278-283, 2011.

[15] Vymazal, J., Plants used in constructed wetlands with horizontal subsurface flow: A review. Hydrobiologia, 674, pp. 133-156, 2011.

[16] REAL DECRETO 1620/2007, de 7 de diciembre, por el que se establece el régimen jurídico de la reutilización de las aguas depuradas.

[17] REGULATION (EU) 2020/741 of the European Parliament and of the Council of 25 May 2020 on minimum requirements for water reuse.

[18] APHA. Standard Methods for the Examination of Water and Wastewater. 21st ed., American Public Health Association/American Water Works Association/Water Environment Federation, Washington DC, 2005.

[19] Ministerio de Medio Ambiente, Estudio para el desarrollo sostenible de l'Albufera de Valencia, 2005. http://www3.chj.gob.es/albufera/01_WEB_ED/indexAV1.htm.

[20] Yang, Y., Tomlinson, D., Kennedy, S. \& Zhao, Y., Dewatered alum sludge: A potential adsorbent for phosphorus removal. Water Science and Technology, 54(5), pp. 207-13, 2006.

[21] Generalitat Valenciana. Evaluación de los Datos de Calidad de Aguas para el Seguimiento de Masas de Agua Fluvial en los Espacios Red Natura 2000. Informe técnico 04/2019, 2012. www.agroambient.gva.es/es/web/biodiversidad/evaluacionde-los-datos-de-calidad-de-aguas-para-el seguimiento-de-masas-de-agua-fluvial-enlos-espacios-red-natura-2000.

[22] ORDEN ARM/2656/2008, de 10 de septiembre, por la que se aprueba la instrucción de planificación hidrológica.

[23] Directive 98/83/EC of 3 November 1998 on the quality of water intended for human consumption. 